\title{
Domestication and Foreignization on the Translation of Yogyakarta Sightseeing Guidebook from Indonesian into English
}

\author{
Muhamad Safi'i*, Sufriati Tanjung
}

Applied Linguistics Department, Graduate School, Yogyakarta State University, Indonesia

*Email: muhamadsafii.2019@student.uny.ac.id

\begin{abstract}
This research is aimed to identify the application of domestication and foreignization on the English translation of the Yogyakarta Sightseeing Guidebook. This research is a descriptive qualitative research conducted by analyzing the English version of the Yogyakarta Sightseeing Guidebook and the researchers try to categorize and elaborate the identified items that indicate domestication and foreignization techniques on the translation. This research finds out that both domestication and foreignization is frequently used on the translation of some particular items. The domestication technique is considered to be used to ensure that the translation can be comprehensible for the readers and the foreignization is considered to be applied to introduce the readers some cultural terms from Indonesian culture that is commonly known and used by the local community of the source language.
\end{abstract}

Keywords - Domestication, foreignization, translation.

\section{INTRODUCTION}

Translation is an activity of transferring written information, idea and thought expressed in one language or source of language to target language [1]. Translating text from one language into another language that does not share the same culture gives the translator choices of strategies or techniques that can be applied in order to produce an adequate and acceptable translation. Translator faces linguistic and cultural challenges between different languages and cultures in translating text [2]. It is considered challenging because translator needs to keep the culture of the original text and in the other hand the translator should also think about the reader understanding of the translation. Translation should be either source- or target-oriented. In this case, source language oriented is considered as foreignization, and the target language oriented is domestication [3]. Translator is always faced with this problem in which some lexical items that should be translated either using foreignization or domestication.

Based on the elaboration above, researchers are interested in investigating the foreignization and domestication on the translation of Yogyakarta Sightseeing Guidebook, a brochure promoting interesting places in Yogyakarta, from Indonesian into English. The document is provided by Tourism Office of Yogyakarta to promote and introduce some tourism places that can be visited by the tourists. Since the purpose of the brochure is as an informative tools to promote tourism places, the translation should be as informative as possible in giving the related information. Therefore, the result of this research is expected to give brief explanation of why either foreignization or domestication is applied in translating particular items.

\section{LITERATURE REVIEW}

In order to produce a good translation, it is necessary to consider which method, strategies, and techniques of translation that should be applied. Molina \& Albir (2002) states that those three terms are essentially different categories. They define translation techniques based on the need to differentiate between method, strategy, and technique and the need for an analysis and functional concept of translation techniques. Furthermore, they state that there are five basic characteristic of translation techniques; they affect the result of the translation, they are classified by the comparison with the original, they affect micro- units of text, they are by nature discursive and contextual, and they are functional. The word 'technique' itself refers to a way of doing an activity in which skill and competence are needed [1], [4].

In translating literature and practice, domestication and foreignization strategies have occupied a great deal [2]. Venuti defines domestication as a strategy which adopts a transparent or fluent style in order to minimize the strangeness of the foreign text for the target language reader [5], [6]. On the other hand, foreignization 
is another strategy in translation in which Schleiermacher's terms, "the translator leaves the writer in peace, as much as possible, and moves the reader toward the writer" [5], [6]. Venuti strongly supports the foreignization approach and claims that a translator's mission is to keep the cultural values of the source language and not manipulate it into the target language [2].

Some researchers have previously conducted investigation on the application of domestication and foreignization on some products of translation. One of them is Mansour (2014) who did an investigation on aimed to apply strategies of domestication and foreignization in translating culture-specific references of an English text into Arabic, where the translator has to make his lher decision on the basis of specific factors such as the background of the readership, the goal of the target text, the message of the source text and the client's purpose in translating the source text [7]. Another research is conducted by Matielo \& Espindola (2011) who investigate the domestication and foreignization on the official and non-official subtitle of TV series Heroes which focuses on identifying the cultural-specific items and the treatment given to them in terms of domestication and foreignization [8].

\section{METHODS}

This research is a descriptive qualitative research that is aimed to investigate the domestication and foreignization applied on the translation of Yogyakarta Sightseeing Guidebook from Indonesian into English version. The sources of this research are the original Indonesian version and the English translation of the brochure. This research is conducted by analyzing the English version, comparing it with the original Indonesian version, and taking notes of the identified elements considered as domestication and foreignization.

\section{ANALYSIS AND DISCUSSION}

This research analyzes the English version of the Yogyakarta Sightseeing Guidebook to identify the application of domestication and foreignization in the process of translating the brochure. In the process of analyzing the brochure, researchers do compare the English version with the Indonesian version in order to find and identify the elements or terms used on both versions. After analyzing the brochure, the application of domestication and foreignization on the translation of the brochure can be seen in the following table.

Table.1. Domestication \& Foreignization

\begin{tabular}{lll}
\hline No. & Technique & Amount \\
\hline $\mathbf{1}$ & Domestication & 11 \\
$\mathbf{2}$ & Foreignization & 10 \\
\hline & Total & 21 \\
\hline
\end{tabular}

The Table 01 above shows that there are 21 data identified as the application of domestication and foreignization. In the following discussion, researchers try to elaborate domestication and foreignization based on the identified data.

The translator of the brochure decides to keep some terms related to name of place and also tries to transfer the term into the culture of the target language. The following example shows the application of both domestication and foreignization

Table.2. Name of Place Data 1

\begin{tabular}{ll}
\hline Indonesian version & English version \\
\hline Kraton Yogyakarta & Sultan's Palace \\
Kraton Yogyakarta adalah & Kraton Yogyakarta or \\
salah satu ikon dari Daerah & Sultan Palace is one of the \\
Istimewa Yogyakarta. & icons of Yogyakarta.
\end{tabular}

The data shown in the Table 02 above shows that the translator uses both domestication and foreignization to translate Kraton Yogyakarta. The translator uses another term 'Sultan Palace' refers to Kraton Yogyakarta to mention its function as the place of the Sultan. The use of foreignization in this case indicates that the translator introduces the common term used in Indonesia.

The same strategy applied by the translator to mention other name of place, it is Masjid Gedhe Kauman that the translator uses the original term of Indonesian and also uses domestication for this name, it is Kauman Grand Mosque. The application of both name has the same function as it is mentioned on the explanation of the previous term, to introduce the common term used by the local community and to make sure that the reader understand the meaning. In this case, translator changes the term Gedhe which is derived from Javanese language that means big to 'Grand'. The same case also applied in translating term of Puro Pakualaman, where the translator uses both domestication, Pakualaman Palace, and foreignization in the translation.

The following table shows the use of domestication for the name of place.

Table.3. Domestication of Name of Place

\begin{tabular}{ll}
\hline Indonesian & English \\
\hline Tugu & Tugu monument \\
Kota Tua & Old City
\end{tabular}

The application of domestication of the term

Tugu in Table 03 is purposed to give more detail of the term in order to give reader an image of the place. Kota Tua, on the other hand, is directly translated word for word to Old City which has the same meaning and sense.

The following table shows the use of foreignization for the name of place. 
The following table shows the example of the use of foreignization on the translation.

Table.4. Foreignization for the name of place

\begin{tabular}{ll}
\hline Indonesian & English \\
\hline Taman Sari adalah & Taman Sari is the answer! \\
jawabannya! & \\
\hline
\end{tabular}

The translator keeps the term Taman Sari as the original version because the passage contains the description of the place. It would be quite awkward if the translator uses domestication for this term.

The analyzed Yogyakarta Sightseeing Guidebook contains several items which is related to the culture of Indonesia. The data can be seen in the following table.

Table.5. Specific Items

\begin{tabular}{|c|c|c|}
\hline Indonesian & English & Technique \\
\hline Pribumi & Indigenous people & Domestication \\
\hline Ziarah & Pilgrimage & Domestication \\
\hline Andong & Horse carts & Domestication \\
\hline Karawitan & $\begin{array}{l}\text { Traditional } \\
\text { music/gamelan }\end{array}$ & Domestication \\
\hline Wayang Golek & $\begin{array}{l}\text { Wooden puppet } \\
\text { show }\end{array}$ & Domestication \\
\hline Macapatan & Javanese poetry & Domestication \\
\hline Batik & Batik & Foreignization \\
\hline Paku Alam & Paku Alam & Foreignization \\
\hline Sri Sultan & Sri Sultan & Foreignization \\
\hline Suling Bambu & Suling Bambu & Foreignization \\
\hline Jemparingan & Jemparingan & Foreignization \\
\hline Patehan & Patehan & Foreignization \\
\hline
\end{tabular}

It can be seen in the Table 05 that translator uses either domestication or foreignization for specific items. Foreignization is applied on some items such as Batik and Jemparingan in order to retain the cultural sense of the text. On the other hand, the domestication is applied on other items in order to describe the meaning or the function of the items. For the example is Andong, it is a traditional vehicle using horse and cart, and there is no particular term in English that can be used referring to the term Andong. Therefore, the translator uses Horse Carts as the equivalent term to refer to it.

\section{CONCLUSION}

This research finds out that the application of the domestication and foreignization techniques on the English translation of Yogyakarta Sightseeing Guidebook is quite frequent particularly on the words or phrases which are name of place or which have cultural meaning and function. The use of domestication that can be seen on the discussion of this research is particularly used to introduce the terms that is commonly known and used by the local community of the source language, while the foreignization technique is used in order to describe the meaning and function of the term. Therefore, there is no rule that obliges the translator to use either foreignization or domestication in the process of translating one language into another. The choice is fully given to the translator.

\section{ACKNOWLEDGEMENTS}

This research is dedicated for the Indonesia Endowment Fund for Education (LPDP) of the Indonesian Ministry of Finance that has financially supported the education of the first author.

\section{REFERENCES}

[1] N. Harared, "Foreignization and Domestication Ideology in Cultural Term Translation of Novel Tuesday With Morrie: Category Household Goods and House Surroundings," J. Arbitrer, vol. 5, no. 2, p. 54, 2018.

[2] S. Elnaili, "Investigating Domestication and Foreignization Strategies in Translating Sinbad of the Arabian Nights," Arab World English J., no. 5, pp. 21-32, 2016.

[3] J. Cui, "A study on the relativity of foreignization and domestication in translation based on data comparison," Commun. Comput. Inf. Sci., vol. 217 CCIS, no. PART 4, pp. 352-356, 2011.

[4] L. Molina and A. H. Albir, "Translation techniques revisited: A dynamic and functionalist approach," Meta, vol. 47, no. 4, pp. 498-512, 2002.

[5] L. Venuti, The Translator's Invisibility: A History of Translation, 2nd Ed. London: Routledge, 2008.

[6] J. Munday, Introducing Translation Studies, 4th Ed. New York: Routledge, 2016.

[7] M. H. Mansour, "Domestication and Foreignization in Translating Culture-Specific References of an English Text into Arabic," Int. J. English Lang. Lit. Stud., vol. 2, no. 2, pp. 23-36, 2014.

[8] R. Matielo and E. B. Espindola, "Domestication and foreignization: An Analysis of Culture-specific Items in Official and Non-official Subtitles of the TV Series Heroes.," Cad. Tradução, vol. 1, no. 27, 2011. 